\title{
High consumption of sucrose induces DNA damage in male Wistar rats
}

\author{
SILVIA I.R. FRANKE ${ }^{1,2}$, PATRÍCIA MOLZ ${ }^{1,2,3}$, CAMILA MAI ${ }^{2}$, JOEL H. ELLWANGER ${ }^{4}$, \\ FERNANDA F. ZENKNER ${ }^{4}$, JORGE A. HORTA ${ }^{1,5}$ and DANIEL PRÁ ${ }^{1,2,5}$
}

\begin{abstract}
${ }^{1}$ Programa de Pós-Graduação em Promoção da Saúde, Departamento de Educação Física e Saúde, Universidade de Santa Cruz do Sul/UNISC, Av. Independência, 2293, Sala 4206, Universitário, 96815-900 Santa Cruz do Sul, RS, Brazil ${ }^{2}$ Laboratório de Nutrição Experimental, Departamento de Educação Física e Saúde, Universidade de Santa Cruz do Sul/UNISC, Av. Independência, 2293, Sala 3031, Universitário, 96815-900 Santa Cruz do Sul, RS, Brazil ${ }^{3}$ Programa de Pós-Graduação em Medicina e Ciências da Saúde, Faculdade de Medicina, Pontifícia Universidade Católica do Rio Grande do Sul/PUCRS, Av. Ipiranga, 6681, Partenon, 90619-900 Porto Alegre, RS, Brazil ${ }^{4}$ Programa de Pós-Graduação em Genética e Biologia Molecular, Departamento de Genética, Universidade Federal do Rio Grande do Sul/UFRGS, Av. Bento Gonçalves, 9500, Prédio 43323M, 91501-970 Porto Alegre, RS, Brazil ${ }^{5}$ Departamento de Biologia e Farmácia, Universidade de Santa Cruz do Sul/UNISC, Av. Independência, 2293, Sala 3529, Universitário, 96815-900 Santa Cruz do Sul, RS, Brazil
\end{abstract}

Manuscript received on September 29, 2016; accepted for publication on January 11, 2017

\begin{abstract}
The purpose of this study was to determine the effects of the high consumption of sucrose on the levels of DNA damage in blood, hippocampus and bone marrow of rats. Male Wistar rats were treated for 4 months with sucrose (10\% for 60 initial days and $34 \%$ for the following 60 days) in drinking water, and then, glycemia and glycated hemoglobin (A1C) were measured. Levels of DNA damage in blood and hippocampus were evaluated by the comet assay. The micronucleus test was used to evaluate chromosomal damages in the bone marrow. The sucrose treatment significantly increased $(p<0.01)$ the serum glucose levels $(\sim 20 \%)$ and A1C $(\sim 60 \%)$. The level of primary DNA damage was significantly increased $(p<0.05)$ in hippocampal cells $(\sim 60 \%)$ but not in peripheral blood leukocytes $(p>0.05)$. Additionally, it was observed a significative increase $(p<0.05)$ in the markers of chromosomal breaks/losses in bone marrow, as indicated by the micronucleus test. This is the first study that evaluated DNA damage induced by high sucrose concentration in the hippocampus and bone marrow of rats. Sucrose-induced DNA damage was observed in both tissues. However, the mechanism of sucrose toxicity on DNA remains unknown.
\end{abstract}

Key words: comet assay, diabetes, DNA damage, glycated hemoglobin, micronucleus, sucrose.

\section{INTRODUCTION}

High consumption of sugar-sweetened beverages is an important risk factor for type 2 diabetes (Ley et al. 2016). It is well known that patients with type

Correspondence to: Silvia Isabel Rech Franke

E-mail: silviafr@unisc.br
2 diabetes have elevated levels of DNA damage (Al-Aubaidy and Jelinek 2011, Palazzo et al. 2012, Binici et al. 2013, Tatsch et al. 2015). DNA damage was shown to occur as a consequence of oxidative stress in several diseases, including diabetes (Rösen et al. 2001, Kowluru and Mishra 2015). In addition to being associated with increased levels 
of DNA damage, diabetes may increase the risk of neuropathologies in the central nervous system (Nelson et al. 2009, Abner et al. 2016).

Oxidative stress is characterized by an imbalance between oxidants and antioxidants in favor of the oxidants. This imbalance can lead to a disruption of redox signaling and control. Furthermore, oxidative stress can cause molecular damages (Sies 2015). In this context, oxidative stress has been implicated in the onset and progression of diabetes and its complications (Rösen et al. 2001, Pitocco et al. 2010).

Despite the association between genotoxicity and diabetes is well studied, the influence of the consumption of sucrose on the levels of DNA damage was little explored. To the best of our knowledge, no study to date has evaluated the genotoxicity of sucrose on the brain or bone marrow cells. Additionally, further studies are needed to understand the impact of hyperglycemia on neuropathologies associated with diabetes. In this context, the purpose of this study was to determine the effects of the high consumption of sucrose on the levels of DNA damage in rats. We must emphasize that this is the first study that aimed to evaluate the influence of the consumption of sucrose on the levels of DNA damage in the hippocampus and bone marrow of rats.

\section{MATERIALS AND METHODS}

\section{ETHICAL ASPECTS, ANIMALS, AND TREATMENTS}

All procedures adopted in this study followed the guidelines for the care and use of animals outlined in the Brazilian regulations for animal studies (Law No. 11794/1999). The experimental procedures were approved by the Ethics in Research Committee of the University of Santa Cruz do Sul (Protocol 2503/10).

Male Wistar rats (90 days old and weighing approximately $250 \mathrm{~g}$ ) were purchased from the Federal University of Santa Maria (Rio Grande do Sul, Brazil) and kept in individual cages under a twelve-hour light/dark cycle at $22 \pm 3{ }^{\circ} \mathrm{C}$ and $60 \%$ humidity. Throughout the experiments, all rats received Purina Labina ${ }^{\circledR}$ chow for laboratory animals (normocaloric diet) ad libitum, and the weights and food intake of the animals were recorded.

After 2 weeks acclimatizing to the vivarium, the rats were randomly divided into 2 groups of 8 rats each: (I) water control and (II) sucrose treatment. The treatments were administered ad libitum in drinking water. The initial concentration dose of sucrose was based on Brito et al. (2007) who induced hyperglycemia in mice by treating them with $10 \%$ sucrose for 60 days. We treated the animals for 60 days at this dose without any noticeable increases in the glucose level. Thus, the concentration of sucrose was increased to $34 \%$ for 60 more days, totalizing 4 months of treatment. The 34\% sucrose concentration has been tested in mice by Glendinning et al. (2010). Water intake was measured weekly to verify the water intake and the water with sucrose intake. Glucose was added weekly in the water offered to the animals. At the end of experiments, the animals were euthanized by decapitation using a guillotine according to standard animal experimentation procedures. No anesthetics were used to prevent drug-induced DNA damage.

\section{GLYCEMIC CONTROL PARAMETERS}

The 12-hour fasting glucose levels were evaluated weekly with a portable Accu-Check Advantage ${ }^{\mathbb{B}}$ glucometer. According to the Animal Models of Diabetic Complications Consortium (AMDCC 2003), rats with $\geq 150 \mathrm{mg} / \mathrm{dL}$ fasting glucose are considered hyperglycemic. To validate the results with the portable glucometer, tests were performed in a specialized laboratory to check blood glucose at the end of the experiment. A test from BioSystems SA (Barcelona, Spain) was applied 
according to the manufacturers' specifications using A25 equipment (Bio Systems, Spain). A1C was measured using HPLC method in the Bio-Rad Variant II Turbo Hemoglobin Testing System (BioRad Laboratories, Hercules, CA, U.S.A.).

TISSUE SAMPLES (BLOOD AND BRAIN)

Blood samples collected at euthanasia were used to mount the comet assay slides. Blood was collected (using microtubes with heparin) from jugular vein immediately after euthanasia. The hippocampal cell suspension of each animal was obtained as follows: the brain was removed immediately after euthanasia and sectioned at the junction between the medulla and spinal cord. Subsequently, the brain was transferred to a Petri dish maintained in an ice bath to extract the hippocampus. The hippocampus was identified with the aid of an acrylic plate for differentiation of brain areas (Insight ${ }^{\circledR}$, Brazil). The coordinates described by Paxinos and Watson (2005) were used for selecting the slice of interest (hippocampal area). The hippocampal tissue was transferred to a microtube containing phosphate buffered saline (PBS) supplemented with $10 \%$ dimethyl sulfoxide (DMSO). The tissue was gently separated with tweezers to allow cell detachment. The resulting cell suspension was used for the comet assay.

\section{COMET ASSAY}

The comet assay was used to determine the levels of DNA damage (Singh et al. 1988). Details of the procedures used in this assay by our research group were recently described in Molz et al. (2016). One hundred nucleoids per sample (50 per slide, two slides per animal) were randomly selected and analyzed using a conventional microscope at 200X magnification. An exemplification of the visual parameters used for the evaluation of the nucleoids can be found in the study of Ellwanger et al. (2015). The damage was determined by the classification of the comets into five classes of DNA migration: damage 0 (no tail) to damage 4 (maximum damage). The damage index (DI) was obtained from the sum of individual cells assigned to each one of the classes of DNA damage, ranging from 0 (no damage: 100 cells $x$ 0) to 400 (maximum damage: 100 cells $\mathrm{x} 4$ ). Nucleoids classified as ghost comets (non-detectable cell nuclei) were not considered for analysis.

\section{TEST OF MICRONUCLEUS IN BONE MARROW ERYTHROCYTES}

At the end of the experiment, the femurs of the animals were removed and slides were prepared as described by Prá et al. (2008). Briefly, bone marrow was mixed with fetal calf serum and smears were prepared with this mixture. Two slides (coded for "blind" analysis) were prepared from each animal. Cells were stained with 5\% Giemsa. The micronuclei were assessed in 2000 polychromatic erythrocytes (PCE) as a marker of chromosomal damage. The ratio of $\{\mathrm{PCE} /[$ normochromatic erythrocytes $(\mathrm{NCE})+\mathrm{PCE}]\}$ was evaluated in 1000 cells as a marker of the toxicity of the treatments.

\section{DATA PROCESSING}

The data were analyzed using GraphPad Prism v 5.1 (Graphpad Inc, San Diego). The variables were compared using t-tests or Mann-Whitney tests. The data were checked for normality before statistical evaluation to choose the test. A $p$-value $<0.05$ was considered significant for all tests.

\section{RESULTS}

Table I shows the A1C and serum glucose levels of the treated animals. Sucrose treatment significantly increased both markers $(p<0.01)$. Table II shows the levels of DNA damage as evaluated by the comet assay in blood and hippocampal cells. Sucrose treatment induced more DNA damage in both tissues (about 20\% for blood and 65\% 
TABLE I

Influence of sucrose treatment on fasting glucose and glycated hemoglobin (A1C) in rats.

\begin{tabular}{ccc}
\hline Treatment & Serum glucose $(\mathbf{m g} / \mathbf{d L})$ & Glycated hemoglobin $(\%)$ \\
\hline Water $(n=8)$ & $76.75 \pm 1.65$ & $5.70 \pm 0.36$ \\
Sucrose $(n=8)$ & $92.73 \pm 1.76^{* *}$ & $9.03 \pm 1.11^{* *}$ \\
\hline
\end{tabular}

**significant at the $p<0.01$ level.

TABLE II

Influence of sucrose treatment on damage index in blood and hippocampus in rats.

\begin{tabular}{ccc}
\hline Treatment & Damage Index in peripheral blood leukocytes (a.u.) & Damage Index in hippocampal cells (a.u.) \\
\hline Water $(n=8)$ & $18.50 \pm 11.90$ & $128.00 \pm 78.81$ \\
Sucrose $(n=8)$ & $22.33 \pm 1.53$ & $210.75 \pm 75.13^{*}$ \\
\hline
\end{tabular}

a.u.: arbitrary unit. *significant at the $p<0.05$ level.

for hippocampus), although damage was only significant in the hippocampus $(p<0.05)$.

Table III shows the results of sucrose treatment on markers of chromosomal mutations (micronucleus) and the PCE/NCE ratio in the bone marrow. Sucrose treatment induced an increase $(p<0.05)$ in the frequency of micronuclei without any sign of cytotoxicity (no change in PCE/NCE ratio).

\section{DISCUSSION}

The rats did not reach a state of hyperglycemia (>150mg/dL glucose, according to AMDCC 2003) during the study period possibly because we did not use drugs to induce diabetes (for example streptozotocin). However, we emphasize that our goal was not to replicate an animal model of diabetes. We used sucrose aiming to induce hyperglycemia because (I) its consumption is linked to the type 2 diabetes (Sonestedt et al. 2012) and (II) the influence of the added sugars on the development of diseases must receive more attention (Kearns et al. 2016). In addition, our main goal was to verify the effect of the high consumption of sucrose on the levels of DNA damage in blood, hippocampus and bone marrow. After an attempt to increase the fasting glucose with the consumption of $10 \%$ sucrose (sucrose concentration of soft drinks or
TABLE III

Influence of sucrose on markers of chromosomal mutations (micronucleus) in rats.

\begin{tabular}{ccc}
\hline Treatment & $\begin{array}{c}\text { Micronuclei in PCE } \\
\text { (PCEMN) (\%o PCE) }\end{array}$ & $\begin{array}{c}\text { PCE/(PCE + } \\
\text { NCE) ratio }\end{array}$ \\
\hline Water $(n=8)$ & $0.80 \pm 0.84$ & $0.61 \pm 0.37$ \\
Sucrose $(n=8)$ & $2.40 \pm 1.14^{*}$ & $0.64 \pm 0.61$ \\
\hline
\end{tabular}

PCE: polychromatic erythrocytes. NCE: normochromatic erythrocytes. *significant at the $p<0.05$ level.

$\sim 90 \mathrm{~g} / \mathrm{L}$ sucrose, according to USDA 2005), no significant increase in glycemia was observed (data not shown). The concentration of sucrose was increased to $34 \%$, which led to a $20 \%$ increase in fasting glucose (approximately $1 \mathrm{mM}$ ).

There is sound evidence that hyperglycemia induces oxidative stress (Miyazaki et al. 2007, Node and Inoue 2009, Savu et al. 2011). Furthermore, elevated levels of oxidative stress and DNA damage are typical findings in diabetic patients (Al-Aubaidy and Jelinek 2011, Binici et al. 2013, Tatsch et al. 2015). Our experimental model did not show a significant association between levels of DNA damage in blood cells and the sucrose treatment. However, we found an association between increased levels of DNA damage in the hippocampal cells and high consumption of sucrose. Sucrose irreversibly glycosylates proteins (Dragsted et al. 2002). In this context, Pischetsrieder et al. (1999) demonstrated that DNA 
glycation reaction is responsible for DNA damage in vivo. Based on these data, we can suggest that, in our study, DNA glycation reactions induced by sucrose could be responsible for DNA damage found in brain cells. Moreover, reducing sugars and reactive products as results of reactions between sugars and amino acids can be causative agents of DNA damage (Mullokandov et al. 1994).

It is well known that high levels of DNA damage contribute to neurodegeneration (Madabhushi et al. 2014, Coppedè and Migliore 2015). This information associated with our results suggest that high levels of DNA damage in hippocampus could be one of the factors that contribute to different neuropathologies found in many patients with diabetes. However, this hypothesis deserves further studies, particularly to understand the putative effects of sugar overload in brain.

Micronuclei originate from chromosomal breaks or losses that can remain after cell division. Bulky DNA lesions are associated with chromosome breaks and micronuclei frequency (Prá et al. 2008). The increase in bone marrow micronuclei frequency in the group of rats treated with sucrose can be related to the capacity of sucrose to induce mutations, as previously observed in the colon of rats treated with sucrose-rich diet (Dragsted et al. 2002). In our study, no signs of cytotoxicity were verified in bone marrow, indicating that the chromosomal damages might accumulate slowly during treatment with sucrose.

In conclusion, our study demonstrated that high consumption of sucrose during a reasonable time length is associated with primary DNA damage in hippocampal cells (as shown by the comet assay) and markers of chromosomal breaks/losses in bone marrow (as verified by the micronucleus test). The mechanism of sucrose toxicity remains unclear. However, it is possible to suggest that oxidative stress induced by the high consumption of sucrose as well as sucrose-induced DNA glycation reactions are possible causes of DNA damage. On the other hand, the influence of other mechanisms cannot be ruled out. In addition, DNA damage could be a contributing factor for diabetes-associated neuropathologies.

\section{ACKNOWLEDGMENTS}

We thank Fundação de Amparo à Pesquisa do Estado do Rio Grande do Sul - FAPERGS (Edital PqG 2010) and Coordenação de Aperfeiçoamento de Pessoal de Nível Superior - CAPES (Edital Nanobiotec) for the financial support. We also thank Paula Fengler, Luiza Louzada Müller, Juliano Assmann and Dr. Deivis de Campos for their help with the experiments and reading of the preliminary version of this article.

\section{REFERENCES}

ABNER EL ET AL. 2016. Diabetes is associated with cerebrovascular but not Alzheimer's disease neuropathology. Alzheimers Dement 12: 882-889.

AL-AUBAIDY HA AND JELINEK HF. 2011. Oxidative DNA damage and obesity in type 2 diabetes mellitus. Eur J Endocrinol 164: 899-904.

AMDCC - ANIMAL MODELS OF DIABETIC COMPLICATIONS CONSORTIUM. 2003. Validation of models of cardiovascular disease in diabetes. AMDCC, p. 1-13.

BINICI DN, KARAMAN A, COŞKUN M, OĞLU AU AND UÇAR F. 2013. Genomic damage in patients with type-2 diabetes mellitus. Genet Couns 24: 149-156.

BRITO VB, FOLMER V, SOARES JCM, SILVEIRA ID AND ROCHA JBT. 2007. Long-term sucrose and glucose consumption decreases the delta-aminolevulinate dehydratase activity in mice. Nutrition 23: 818-826.

COPPEDÈ AND MIGLIORE L. 2015. DNA damage in neurodegenerative diseases. Mutat Res 776: 84-97.

DRAGSTED LO ET AL. 2002. A sucrose-rich diet induces mutations in the rat colon. Cancer Res 62: 4339-4345.

ELLWANGER JH, MOLZ P, DALLEMOLE DR, PEREIRA DOS SANTOS A, MÜLLER TE, CAPPELLETTI L, GONÇALVES DA SILVA M, FRANKE SIR, PRÁ D AND PEGAS HENRIQUES JAP. 2015. Selenium reduces bradykinesia and DNA damage in a rat model of Parkinson's disease. Nutrition 31: 359-365.

GLENDINNING JI, BREINAGER L, KYRILLOU E, LACUNA K, ROCHA R AND SCLAFANI A. 2010. Differential effects of sucrose and fructose on dietary obesity in four mouse strains. Physiol Behav 101: 331-343. 
KEARNS CE, SCHMIDT LA AND GLANTZ SA. 2016. Sugar industry and coronary heart disease research: a historical analysis of internal industry documents. JAMA Intern Med 176: 1680-1685.

KOWLURU RA AND MISHRA M. 2015. Oxidative stress, mitochondrial damage and diabetic retinopathy. Biochim Biophys Acta 1852: 2474-2483.

LEY SH, ARDISSON KORAT AV, SUN Q, TOBIAS DK, ZHANG C, QI L, WILLETT WC, MANSON JE AND HU FB. 2016. Contribution of the Nurses' Health Studies to uncovering risk factors for type 2 diabetes: diet, lifestyle, biomarkers, and genetics. Am J Public Health 106: 16241630.

MADABHUSHI R, PAN L AND TSAI LH. 2014. DNA damage and its links to neurodegeneration. Neuron 83: 266-282.

MIYAZAKI Y, KAWANO H, YOSHIDA T, MIYAMOTO S, HOKAMAKI J, NAGAYOSHI Y, YAMABE H, NAKAMURA H, YODOI J AND OGAWA H. 2007. Pancreatic B-cell function is altered by oxidative stress induced by acute hyperglycaemia. Diabet Med 24: 154160.

MOLZ P, ELLWANGER JH, ZENKNER FF, CAMPOS D, PRÁ D, PUTZKE MTL AND FRANKE SIR. 2016. Recognition memory and DNA damage in undernourished young rats. An Acad Bras Cienc 88: 1863-1873.

MULLOKANDOV EA, FRANKLIN WA AND BROWNLEE M. 1994. DNA damage by the glycation products of glyceraldehyde 3-phosphate and lysine. Diabetologia 37: 145-149.

NELSON PT ET AL. 2009. Human cerebral neuropathology of Type 2 diabetes mellitus. Biochim Biophys Acta 1792: 454-469.

NODE K AND INOUE T. 2009. Postprandial hyperglycemia as an etiological factor in vascular failure. Cardiovasc Diabetol 8: 23.

PALAZZO RP, BAGATINI PB, SCHEFER PB, DE ANDRADE FM AND MALUF SW. 2012. Genomic instability in patients with type 2 diabetes mellitus on hemodialysis. Rev Bras Hematol Hemoter 34: 31-35.

PAXINOS G AND WATSON O. 2005. The rat brain in stereotaxic coordinates. $5^{\text {th }}$ ed., San Diego: Elsevier.

PISCHETSRIEDER M, SEIDEL W, MÜNCH G AND SCHINZELR. 1999. $N^{2}$-(1-Carboxyethyl)deoxyguanosine, a nonenzymatic glycation adduct of DNA, induces single- strand breaks and increases mutation frequencies. Biochem Biophys Res Commun 264: 544-549.

PITOCCO D, ZACCARDI F, DI STASIO E, ROMITELLI F, SANTINI SA, ZUPPI C AND GHIRLANDA G. 2010. Oxidative stress, nitric oxide, and diabetes. Rev Diabet Stud 7: 15-25.

PRÁ D, FRANKE SIR, GIULIAN R, YONEAMA ML, DIAS JF, ERDTMANN B AND HENRIQUES JAP. 2008. Genotoxicity and mutagenicity of iron and copper in mice. Biometals 21: 289-297.

RÖSEN P, NAWROTH PP, KING G, MÖLLER W, TRITSCHLER HJ AND PACKER L. 2001. The role of oxidative stress in the onset and progression of diabetes and its complications: a summary of a Congress Series sponsored by UNESCO-MCBN, the American Diabetes Association and the German Diabetes Society. Diabetes Metab Res Rev 17: 189-212.

SAVU O, SUNKARI VG, BOTUSAN IR, GRÜNLER J, NIKOSHKOV A AND CATRINA SB. 2011. Stability of mitochondrial DNA against reactive oxygen species (ROS) generated in diabetes. Diabetes Metab Res Rev 27: 470-479.

SIES H. 2015. Oxidative stress: a concept in redox biology and medicine. Redox Biol 4: 180-183.

SINGH NP, MCCOY MT, TICE RR AND SCHNEIDER EL. 1988. A simple technique for quantitation of low levels of DNA damage in individual cells. Exp Cell Res 175: 184-191.

SONESTEDT E, ØVERBY NC, LAAKSONEN DE AND BIRGISDOTTIR BE. 2012. Does high sugar consumption exacerbate cardiometabolic risk factors and increase the risk of type 2 diabetes and cardiovascular disease? Food Nutr Res 56: 19104.

TATSCH E ET AL. 2015. Oxidative DNA damage is associated with inflammatory response, insulin resistance and microvascular complications in type 2 diabetes. Mutat Res 782: 17-22.

USDA - U.S. DEPARTMENT OF AGRICULTURE, Agricultural Research Service. 2005. National Nutrient Database for Standard Reference, Release 18. USDA. 